\title{
Creation and profit earning capacity of a rabbitry
}

\author{
J. P. OLIVE \\ École d'Avicultuve C.E.Z., Parc du Château, \\ 78120 Rambouillet (France)
}

After having transformed a poultry house into a hutch divided into two sections (a kindling section equiped with 88 Flat Deck cages, a fattening section with 120 cages arranged in 3 -store batteries) we started a technico-economic management trial based on the supervision of a small number of " warning thresholds".

The herd was first managed according to the linear planning rule with operations on definite days and then intensively with post-partum matings.

Nine criteria were retained for the analysis of the technical results. It appeared that for 2 of these criteria (number of young weaned per doe cage, interval between kindlings : 55 days) a particular effort had to be made, the objective being to obtain a result of 300 FF per doe cage for the return to labour and capital.

On account of the constraints of our rabbitry, this result indicates that the interval between kindlings must be 47 days and the number of young per hutch and per year: $5 \mathrm{I}$. Thus, at the end of each month, we analyse these 2 criteria with the aim of intervening if necessary.

The profit-earning capacity of a rabbit production unit depends on a rigorous management system.

V. - GENETICS

\section{Study of genetic variation in 2 way and 3 way crossings in the rabbit : reproductive performances of does}

\author{
G. MATHERON et R. ROUVIER \\ Station d'amélioration génétique des animaux, \\ Centre de Recherches de Toulouse, I.N.R.A., 3 I320 Castanet-Tolosan (France)
}

An experiment of single crossing with 6 breeds of males (Géant Blanc du Bouscat, Argenté de Champagne, Fauve de Bourgogne, Californian, New Zealand and Petit Russe) and 3 breeds of females (Californian, New Zealand and Petit Russe) showed the effect of the male on the litter size of the female to which it was mated because of the viability genes transmitted to the embryo. Moreover, an heterosis of ro to $44 \mathrm{P}$. Ioo on the litter size was noticed. An experiment of 3-way crossing (females of the 9 genotypes obtained by crossing of the three female breeds from the former experiment) using a single male genotype (Fauve de Bourgogne) showed an additional heterosis effect of $8 \mathrm{p}$. I 00 on the litter size. Between breeds there seemed to be an opposition between the direct effects of viability genes and the number of ova produced. Finally, between breeds, the direct and maternal effects seemed to be in opposition for each of these two characters. 